\title{
ISOKINETIC PROFILES AND REFERENCE VALUES OF PROFESSIONAL SOCCER PLAYERS
}

\section{PERFIL ISOCINÉTICO Y VALORES DE REFERENCIA DE FUTBOLISTAS PROFESIONALES}

Guillermo Charneco Salguero' (iD (Sports Medicine Nurse, Physical Therapist)

Francisco García-Muro San José ${ }^{10}$ (Physical Therapist)

Arturo Pérez Gosalvez 1 (iD (Physical Therapist) Jose Miguel Cárdenas Rebollo' (iD (Statistician)

Isabel Brígido Fernández' (iD (Physical Therapist)

Luis Fernández Rosa' (1D)

(Sports Medicine Doctor)

1. Universidad San Pablo-CEU, CEU Universities, School of Medicine, Urbanización Montepríncipe, Boadilla del Monte, Spain.

\section{Correspondence}

Francisco García-Muro San José San Pablo CEU University CEU. School of Medicine. Physiotherapy Department. Avda. de Montepríncipe s/n. Boadilla del Monte. Madrid. Spain. 28668. fgarciamuro@ceu.es

\begin{abstract}
Introduction: Isokinetics is a tool commonly used in professional soccer. There is ongoing debate among researchers as to the isokinetic reference values a player should have. Objectives: To determine the absolute peak torque (PT) and average work of professional soccer players in relation to their positions on the field, and to establish the reference values for these variables. Methods: Purposeful sampling was used to select 289 professional soccer players. The sample included 32 goalkeepers, 100 defenders, 98 midfielders, and 59 strikers. The participants were measured preseason. The players were asked to perform a 10-minute warm-up on an exercise bike, and then to perform 5 repetitions at low speed, 10 at medium speed, and 25 at high speed, with 30 to 40-s of rest between each set of repetitions. The contraction method was concentric-concentric in a dynamometer Isomed 2000. Results: The average age, weight, and height of the players was 21.9 years, 74.3 kilograms, and 1.8 meters, respectively. The goalkeepers presented higher PT at the 3 measured speeds, and the higher average work at $180 \% \mathrm{~s}$ and $240 \% \mathrm{~s}$ in relation to defenders and midfielders. The strikers presented higher average work at $240 \% \mathrm{~s}$ in relation to midfielders, and higher PT in relation to the defenders and midfielders. Absolute values were shown and reference values were established. Conclusions: The goalkeepers and strikers were the players that showed the greatest differences in their favor in relation to the other positions. The peak torque values and average work were described in relation to the player's position on the field. This study resulted in the creation of a tool for health professionals working with professional soccer players, providing reference values for these players in relation to their position on the field that can be used as benchmarks, by health professionals, to optimize soccer players' performance. Level of evidence II, Prospective comparative study.
\end{abstract}

Keywords: Soccer; Reference values; Torque; Work.

\section{RESUMO}

Introdução: A isocinética é uma ferramenta comum usada no futebol profissional. Entre os pesquisadores, há um debate contínuo sobre os valores isocinéticos de referência que um jogador deve ter. Objetivos: Determinar o pico de torque (PT) absoluto e o trabalho médio de jogadores de futebol profissional com relação às posições em campo e estabelecer os valores de referência para essas variáveis. MÉTODOS: Foi selecionada uma amostra subjetiva de 289 jogadores de futebol profissional. A amostra incluiu 32 goleiros, 100 zagueiros, 98 meio-campistas e 59 atacantes. Os participantes foram testados na pré-temporada. Os participantes foram solicitados a realizar aquecimento de 10 minutos em bicicleta ergométrica e, a seguir, realizar cinco repetições em baixa velocidade, 10 em velocidade média e 25 em alta velocidade com 30 a 40 segundos de descanso entre cada série de repetições. 0 método de contração foi concêntrico-concêntrico em um dinamômetro Isomed 2000. Resultados: A média de idade, peso e estatura dos jogadores foi de 21,9 anos, 74,3 quilos e 1,8 metros, respectivamente. Os goleiros apresentaram maior PT nas três velocidades medidas e maior média de trabalho a 180\% e $240 \% \mathrm{scom}$ relação aos zagueirose meio-campistas. Os atacantes tiveram maior trabalho médio a $240 \% \mathrm{scom}$ relação aos meio-campistas e maior PT com relação aos zagueiros e meio-campistas. Os valores absolutos foram mostrados e os valores de referência foram estabelecidos. Conclusões: Os goleiros e atacantes apresentaram as maiores diferenças a seu favor com relação às demais posições. Os valores de pico de torque e trabalho médio foram descritos com relação à posição do jogador em campo. Este estudo resultou na criação de uma ferramenta para profissionais de saúde que atuam com jogadores de futebol profissional e forneceu valores de referência para esses jogadores com relação à posição em campo que podem ser usados como referência para otimizar o desempenho dos jogadores de futebol. Nível de evidência ll, Estudo retrospectivo comparativo.

Descritores: Futebol; Valores de referência; Torque; Trabalho.

\section{RESUMEN}

Introducción: La evaluación isocinética es una herramienta de uso común en el fútbol profesional. Sigue existiendo debate entre los investigadores sobre los valores isocinéticos de referencia que debe tener un jugador. Objetivos: Determinar el torque máximo (TM) y el trabajo promedio de los futbolistas profesionales en relación a sus posiciones en el 
campo yestablecer los valores de referencia para estas variables. MÉTODOS: Se seleccionó una muestra subjetiva de 289 futbolistas profesionales. Se incluyeron 32 porteros, 100 defensas, 98 centrocampistas y 59 delanteros. Los participantes fueron examinados en la pretemporada. Se solicitó a los participantes que realizaran un calentamiento de 10 minutos en bicicleta estática y luego realizar 5 repeticiones a baja velocidad, 10 a velocidad media y 25 a alta velocidad con 30 a 40 segundos de descanso entre cada serie de repeticiones. El método de contracción fue concéntrico-concéntrico en dinamómetro Isomed 2000. Resultados: La edad, el peso y la altura promedios de los jugadores fue de 21,9 años, 74,3 kilogramos y 1,8 metros, respectivamente. Los porteros presentaron TM más elevado en las 3 velocidades medidas y un mayor trabajo promedio a 180\% y 240\%s en relación a defensas y centrocampistas. Los delanteros presentaron un mayor trabajo promedio a $240 \%$ s en relación con los centrocampistas y TM más elevado en relación a defensas y centrocampistas. Se mostraron los valores absolutos y se establecieron los valores de referencia. Conclusiones: Los porteros y delanteros fueron los que mostraron mayores diferencias a su favor en relación al resto. Los valores de torque máximo y el trabajo promedio fueron descritos en relación a la posición del jugador en el campo. Los resultados del presente estudio son una herramienta para los profesionales de la salud que trabajan con futbolistas profesionales y proporcionó valores de referencia para estos futbolistas en lo que respecta a su posición que pueden utilizarse como referencia para optimizar el rendimiento. Nivel de evidencia II, Estudio comparativo retrospectivo.

Descriptores: Fútbol; Valores de referencia; Torque; Trabajo.

\section{INTRODUCTION}

Soccer is played by approximately 128,893 professional players around the world. ${ }^{1}$ The physical demands of players in different positions on the field vary considerably. ${ }^{2}$ Thus, one may assume that there may be differences between muscle parameters for the various positions on the field. ${ }^{3,4}$ Isokinetics is regarded as a sufficiently valid and reliable tool that may be employed for the prevention, diagnosis, and treatment of lower limb injuries in professional soccer players. ${ }^{5}$ The dynamometer may be employed for the evaluation of performance and effective muscular capacity; in addition, it allows for muscle training in processes of functional re-education. Peak torque (PT) is one of the most frequently used isokinetic variables. PT measurement is a method that is frequently employed for the objectification and evaluation of professional soccer players'strength.

Isokinetic dynamometers also allow one to measure work. Average work has been shown to be the most sensitive isokinetic parameter that can be employed to detect significant differences between soccer players' different positions in the field, particularly at medium to high angular velocities. However, few studies have examined the impact that work measurement can have on professional soccer players. . $^{3,4,6,7}$ However, despite years of research, there are not only pending discrepancies regarding the ideal isokinetic profile that professional soccer players should have but also a dearth of studies that have defined reference values for this group. The elaboration of certain reference values should be based on a correct selection of reference individuals, inclusion and exclusion criteria, and defined participation criteria. ${ }^{8}$

These determinations are intended to comprise a reliable, objective, reproducible, and standard tool for health science professionals so as to quantify the physical condition of soccer players under their responsibility.

\section{MATERIALS AND METHODS}

The participants comprised 289 professional male soccer players from first and second division Spanish soccer teams. The study was conducted during the pre-season. Purposeful sampling was employed, and prior to participation, each player was verbally informed of the intent of the research and signed an informed consent form. Each participant was coded to ensure his anonymity. This study was approved by the ethics committee of CEU-San Pablo University (approval code: 238/17/18). Players who had undergone surgery in the previous 12 months for any lower limb pathology or who had suffered a lower limb injury that compelled him to suspend his sporting activities for at least one month were excluded. Furthermore, anyplayer with a history of a disorder that at the time contraindicated, both relatively and absolutely, the performance of an assessment of isokinetic dynamics of the knee joint was excluded.

Prior to the isokinetic evaluation, each participant was asked to warm up the muscle groups that were to be evaluated by pedaling a stationary bike for 10-min at medium intensity. The seat height had to allow an extension close to $0^{\circ}$ when the participant extended each lower limb. During this period, the participants were instructed to maintain a comfortable resistance and pedaling cadence to avoid pre-test fatigue. ${ }^{9}$ Thereafter, the participantsat in a dynamometer chair that formed an $85^{\circ}$ angle between the back and seat before proceeding to adjust the safety straps around his chest, waist, and right thigh. The secondary dynamometer adapter was aligned with the participant's tibial spine $2.5 \mathrm{~cm}$ from the right tibial malleolus; after ensuring that it was comfortable for the player, it was secured with a strap. ${ }^{10}$ Prior to the assessment of each speed, the participant was asked to perform three to five submaximal contractions of increasing intensity (25\%-50\%-80\%) to complete the established range for both knee flexion and extension in order to adapt the musculature for the effort that would be required later. ${ }^{11}$ The series established by the protocol required five flexion/extension concentric contractions at $60 \%$ s, 10 at $180 \%$ s, and 25 at $240 \%$ s ; the participants were required to perform these at maximum intensity. Subsequently, after resting between 30 and 40-s, during which time the dynamometer was adjusted.

SPSS Statistics Version 24 program was employed for the analyses. Furthermore, an alpha level of 0.05 was considered significant for all the analyses.

\section{Ethical considerations}

Each participant was coded to ensure his anonymity. This study was approved by the ethics committee of CEU-San Pablo University (approval code: 238/17/18).

\section{RESULTS}

Detailed soccer characteristics of the participants are provided in Table 1.

Peak torque results and average work results are described in Table 2 and Table 3 respectively.

\section{Angular speed of $60 \%$}

In relation to PT,overall and for knee extensions, significant differences were found between the goalkeepers and defenders $(p=0.008)$ and between the goalkeepers and midfielders $(p=0.037)$. The values obtained for PT for the goalkeepers'leg extensions were statistically superior 
Table 1. Participant characteristics, mean \pm SD.

\begin{tabular}{|c|c|c|c|c|c|}
\hline & Total & Goalkeepers & Defenders & Midfielders & Strikers \\
\hline Age (y) & $21.9 \pm 4.2$ & $21.7 \pm 4.6$ & $22.5 \pm 4.7$ & $21.6 \pm 4.0$ & $21.2 \pm 3.5$ \\
\hline Body height (cm) & $180.1 \pm 5.9$ & $186.9 \pm 4.9 a, b, c$ & $180.6 \pm 4.9 a, d$ & $177.9 \pm 5.3 b, d$ & $179.1 \pm 6.1 c$ \\
\hline Body mass (kg) & $74.3 \pm 6.5$ & $81.4 \pm 6.8 a, b, c$ & $74.7 \pm 5.4 a, d$ & $72.1 \pm 5.7 b, d$ & $73.4 \pm 6.5 c$ \\
\hline Body mass index $\left(\mathrm{kg} / \mathrm{m}^{2}\right)$ & $22.8 \pm 1.3$ & $23.2 \pm 1.5$ & $22.9 \pm 1.2$ & $22.9 \pm 1.2$ & $22.8 \pm 1.4$ \\
\hline Preferred leg & $r=212 ; L=77$ & $R=25 ; L=7$ & $R=66 ; L=34$ & $R=68 ; L=30$ & $R=53 ; L=6$ \\
\hline
\end{tabular}

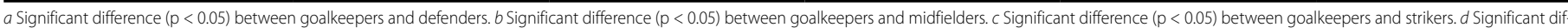
ference $(p<0.05)$ between defenders and midfielders. Abbreviations: $y$, years; $c m$, centimeters; $k g$, kilograms; $R$, right; $L$, left.

Table 2. Means and standards deviations of extension and flexion torque values at different angular velocities, relative to position on field.

\begin{tabular}{|c|c|c|c|c|c|c|}
\hline \multirow[b]{2}{*}{ Extension } & \multicolumn{2}{|c|}{ Peak torque $60(\mathrm{Nm})$} & \multicolumn{2}{|c|}{ Peak torque $180(\mathrm{Nm})$} & \multicolumn{2}{|c|}{ Peak torque $240(\mathrm{Nm})$} \\
\hline & Right & Left & Right & Left & Right & Left \\
\hline goalkeepers & $245.47 \pm 46.15$ & $246.25 \pm 38.32 a$ & $195.07 \pm 23.56 b$ & $192.73 \pm 27.88 d$ & $162.47 \pm 20.32$ & $160.60 \pm 23.25 e$ \\
\hline Defenders & $227.21 \pm 40.41$ & $218.92 \pm 42.90 a$ & $178.92 \pm 29.52$ & $174.31 \pm 23.44 d$ & $149.49 \pm 24.87$ & $144.00 \pm 26.86 e$ \\
\hline Midfielders & $232.13 \pm 37.38$ & $222.87 \pm 39.93 a$ & $173.20 \pm 27.78 b$ & $171.27 \pm 25.93 d$ & $145.14 \pm 23.54$ & $145.93 \pm 22.22 e$ \\
\hline Strikers media & $\begin{array}{l}244.10 \pm 42.13 \\
234.35 \pm 40.88 \\
\end{array}$ & $\begin{array}{l}229.93 \pm 43.47 \\
225.53 \pm 42.16 \\
\end{array}$ & $\begin{array}{l}179.65 \pm 35.06 \\
178.90 \pm 30.14 \\
\end{array}$ & $\begin{array}{l}177.89 \pm 26.03 \\
176.07 \pm 26.02 \\
\end{array}$ & $\begin{array}{l}157.40 \pm 24.15 \\
151.15 \pm 24.42 \\
\end{array}$ & $\begin{array}{l}150.05 \pm 25.65 \\
147.77 \pm 25.11 \\
\end{array}$ \\
\hline \multicolumn{7}{|l|}{ Flexion } \\
\hline Goalkeepers & $143.66 \pm 20.30$ & $129.13 \pm 27.71$ & $119.33 \pm 19.04$ & $106.23 \pm 22.70$ & $107.13 \pm 19.93$ & $95.37 \pm 20.02$ \\
\hline Defenders & $140.64 \pm 38.46$ & $132.31 \pm 46.80$ & $113.23 \pm 19.33$ & $106.42 \pm 17.86$ & $100.40 \pm 17.07 c$ & $93.33 \pm 20.69$ \\
\hline Midfielders & $139.74 \pm 20.69$ & $125.65 \pm 24.66$ & $114.48 \pm 31.31$ & $107.72 \pm 31.24$ & $99.19 \pm 16.04 c$ & $92.67 \pm 15.20$ \\
\hline Strikers media & $\begin{array}{l}141.59 \pm 25.97 \\
140.87 \pm 28.88\end{array}$ & $\begin{array}{l}130.47 \pm 24.44 \\
129.33 \pm 34.19\end{array}$ & $\begin{array}{l}118.04 \pm 21.16 \\
115.36 \pm 24.42\end{array}$ & $\begin{array}{l}111.88 \pm 19.66 \\
108.00 \pm 24.08\end{array}$ & $\begin{array}{c}109.10 \pm 17.77 c \\
102.59 \pm 17.61\end{array}$ & $\begin{array}{l}99.98 \pm 22.47 \\
94.75 \pm 19.47\end{array}$ \\
\hline
\end{tabular}

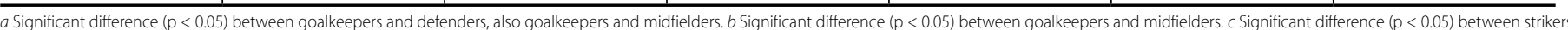

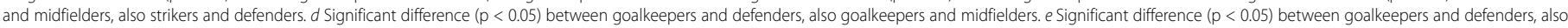
goalkeepers and midfielders. Abbreviations: Nm, newton meter.

Table 3. Means and standards deviations of extension and flexion medium work values at different angular velocities, relative to position on field.

\begin{tabular}{|c|c|c|c|c|c|c|}
\hline \multirow[b]{2}{*}{ Extension } & \multicolumn{2}{|c|}{ Average work $60(\mathrm{~J})$} & \multicolumn{2}{|c|}{ Average work $180(\mathrm{~J})$} & \multicolumn{2}{|c|}{ Average work $240(\mathrm{~J})$} \\
\hline & Right & Left & Right & Left & Right & Left \\
\hline goalkeepers & $242.20 \pm 41.64$ & $224.01 \pm 63.91$ & $188.25 \pm 28.90 a$ & $187.31 \pm 30.95$ & $119.72 \pm 17.01$ & $119.08 \pm 17.37$ \\
\hline Defenders & $215.22 \pm 40.10$ & $215.82 \pm 42.26$ & $173.43 \pm 30.13$ & $170.66 \pm 26.94$ & $114.81 \pm 22.72$ & $111.85 \pm 25.12$ \\
\hline Midfielders & $220.50 \pm 36.45$ & $220.17 \pm 42.09$ & $167.38 \pm 31.34 a$ & $170.52 \pm 29.11$ & $109.12 \pm 24.28$ & $113.39 \pm 19.83$ \\
\hline Strikers & $220.99 \pm 48.11$ & $218.21 \pm 45.88$ & $171.80 \pm 35.02$ & $173.50 \pm 28.26$ & $115.09 \pm 24.21$ & $116.89 \pm 21.95$ \\
\hline Media flexion & $221.18 \pm 41.41$ & $218.70 \pm 45.62$ & $172.65 \pm 31.92$ & $173.06 \pm 28.74$ & $113.51 \pm 23.18$ & $114.24 \pm 22.01$ \\
\hline Goalkeepers & $156.39 \pm 29.71$ & $144.17 \pm 30.86$ & $119.80 \pm 19.83$ & $106.79 \pm 24.96$ & $76.93 \pm 17.09$ & $66.34 \pm 17.62$ \\
\hline Defenders & $148.21 \pm 33.37$ & $143.55 \pm 42.25$ & $115.42 \pm 22.03$ & $105.47 \pm 24.58$ & $75.03 \pm 17.65$ & $69.55 \pm 16.96$ \\
\hline Midfielders & $151.36 \pm 27.87$ & $141.00 \pm 29.10$ & $116.19 \pm 28.72$ & $106.63 \pm 29.97$ & $72.62 \pm 14.58 b$ & $65.54 \pm 16.11 c$ \\
\hline Strikers & $148.07 \pm 33.22$ & $141.96 \pm 28.99$ & $117.69 \pm 26.47$ & $111.76 \pm 21.18$ & $80.24 \pm 19.15 b$ & $73.60 \pm 16.36 c$ \\
\hline Media & $150.15 \pm 31.12$ & $142.43 \pm 34.24$ & $116.65 \pm 25.18$ & $107.34 \pm 25.95$ & $75.54 \pm 17.11$ & $68.72 \pm 16.82$ \\
\hline
\end{tabular}

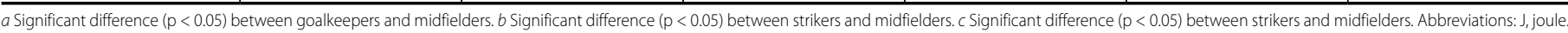

to those of the defenders ( $p=0.008)$ and midfielders $(p=0.037)$. No statisticalley significant difference was found in relation to the average work in this angular velocity.

\section{Angular speed of $180^{\circ} / \mathrm{s}$}

In relation to $P T$,overall and for knee extensions, significant differences were found between the goalkeepers and defenders ( $p<0.001)$, between the goalkeepers and midfielders $(p<0.001)$, between the goalkeepers and strikers $(p=0.034)$, and between the strikers and midfielders ( $p=0.026$ ). The PT values for the goalkeepers' left leg extensions were higher than those of the defenders $(p=0.004)$ and midfielders $(p<0.001)$.

In relation to the average extension work, significant differences were found between the goalkeepers and midfielders $(p=0.001)$ and between the goalkeepers and defenders $(p=0.027)$. The PT values of the goalkeepers' right leg extensions were statistically higher than those of the midfielders ( $p=0.003$ ). Compared to the midfielders, the goalkeepers also performed significantly higher average work for the right leg extensions $(p=0.011)$.

\section{Angular speed of $240 \% \mathrm{~s}$}

In relation to PT,overall and for knee extensions, significant differences were found between the strikers and midfielders $(p=0.012)$ and the strikers and defenders $(p=0.047)$. A statistical significance was also found among goalkeepers and defenders $(p=0.001)$ and midfielders $(p<0.001)$. The strikers scored significantly higher than the defenders ( $p=0.017)$ for PT in the right leg flexion. The strikers also scored higher than the midfielders ( $p=0.004$ ) for PT in the right leg flexion. The PT in the left leg extension was significantly higher in the goalkeepers than the defenders $(p=0.009)$ and higher in the goalkeepers than midfielders $(p=0.031)$.

In relation to the average work involved in bending, significant differences were found between the strikers and midfielders $(p=0.002)$. Strikers had significantly higher workloads compared to midfielders $(p=0.048)$ in the right leg flexion. Strikers obtained significantly higher values $(p=0.025)$ than the midfielders in left leg bending.

\section{DISCUSSION}

\section{Position on the field of play}

In this study, the players' isokinetic values vary in relation to their positions on the field. Thus, as in this study, it is imperative to examine each player's values in relation to the position he occupies and not overall. In the present study and in another study..$^{12}$ Goalkeepers who on average are older and have a higher level of training than the other 
players are likely to have trained for more years and have consequently developed higher PT values. This concurs with previous studies. ${ }^{13-15}$ Various significant differences between different positions became apparent herein. The PT values of the left leg extensions were statistically significant in relation to the defenders and midfielders In particular,it is worth considering the modifications in the methodologies of training according to position that have been evolving and are being optimized. Given time and the continuing development of professional soccer, these various methodologies will be able to alter these inter-positional differences. Moreover, as mentioned previously, Ramírez ${ }^{12}$ also found that goalkeepers had higher torque in extension at an angular speed of $120 \%$ s. Different circumstances may explain these higher values. The specific work that goalkeepers often engage in separately from the rest of their teammates can make them stronger.

The tendency of goalkeepers to have a higher PT can be observed in recent studies: Herdy et al. ${ }^{16}$ found that Brazilian goalkeepers also had the highest total values, although their sample was smaller than the one herein and their participants were younger than 20 years of age. Notably, in both the present study and that of Tsiokanos et al. the goalkeepers were the heaviest players and had the highest PT values. Thus, if the relation of strength to weight had been considered here, the statistical significance in favor of goalkeepers may have differed. ${ }^{17}$ At an angular velocity of $180^{\circ} \%$, the goalkeepers also obtained significantly higher PT values for extensions compared to right-leg midfielders and higher PT for left leg extensions in comparison to defenders and midfielders. This trend at medium speeds has been found in several studies. 12,16,17

Therefore, one may question whether the position in the field truly determines the greater development of PT and the nature of the influence of variables such as weight, mass, height, and age, which may determine these higher values. However, the reality of soccer, as shown in this study, is that some players have a higher PT. Professionals who optimize the performance of soccer players should take this into consideration. It should be noted that different circumstances in each team such as the type of training, the methodologies, and the system of play, which may depend on the specific league and/or technical body, may influence these values. In this study, although nonsignificant, extension PT values at $60 \%$ were also observed in forwards' higher right legs. Similarly, flexion at this same angular velocity for forwards was also found to be significant by Tourny et al. ${ }^{18}$ At $60^{\circ} / \mathrm{s}$ flexion, although nonsignificant, the defenders exhibited higher values. This is in accordance with studies who found higher values for flexors and extenders in this position but whose results in a sample with no goalkeepers were not significant. However, other studies ${ }^{3}$ have found that the goalkeepers exhibited the lowest values. These findings reinforce the notion that regardless of the position on the field, the type of training and specific skills needed to develop one game system have a fundamental influence in the development of these higher PTs. At high angular velocities $(240 \% \mathrm{~s})$, we found that the strikers obtained significantly higher values than the defenders in the right leg bending PT. This was possibly due to the specific resistance work and vertical displacement that strikers tend to develop as part of their offensive play.

As noted previously, it was considered appropriate to measure the participants' average work. The results showed that the work was significantly higher in strikers compared to midfielders in relation to the bending of their left and right leg. These results concur with other studies; ${ }^{4}$ nonetheless, it should be noted that unlike the present study, all the players in the study by Goulart et al. ${ }^{4}$ were under 20 years of age. Depending on the system of play, strikers cover long distances in a match and changes of pace are frequent, which could explain these higher levels of work. We are of the view that average work is a variable that must be considered and analyzed.

Sliwoski's study ${ }^{3}$ shows no average work differences between different positions in the field. Our study determined values $180 \%$ s higher in the goalkeepers than in the midfielders. Goalkeepers have increasingly specialized training sessions that are different from the rest of their teammates since their needs are different. More and more teams train by lines of play, so the training sessions focused on each position on the field. ${ }^{19,20}$ We can therefore expect increasing differences among the positions on the field in the coming years.

PT reveals that a muscle can develop a certain force in a given moment. The work provides information on how the muscle responds in general terms and the capacity a player has to maintain a prolonged effort for a specific time. ${ }^{3}$

We intend to analyze PT and average work to assess overall muscle function. Furthermore, it is imperative to consider that optimal muscle capacity is exhibited in adequate average work values.

\section{Isokinetic profile and reference values}

The isokinetic profile revealed by various studies has differed, which may be due to numerous factors including age, height, weight, years of regular football practice, degree and type of training, and each individual's particular muscle physiology. The normative values and 95\% confidence intervals expected for the sample are presented in Tables 4 and 5. The present study found results that were similar to those of others in relation to absolute PT for extensions ${ }^{19-23}$ and for the flexor muscle group. 19,21,22,24 However, with respect to PT in extension and flexion, the results of this study differed from other studies. $17,18,23,25$ The goalkeepers in our study exhibited very high values, whereas in Tourny-Chollet's study, ${ }_{1}^{18}$ there were no goalkeepers, which could explain the lower values found therein. The players in Tsiokanos ${ }^{17}$ study presented higher values than those herein for all the players. This included their sample of goalkeepers who were older than the goalkeepers in this study and had developed greater strength than the rest of the players. Consequently, there appears to be a relationship between the average age of participants, years of training, and the values of developed PT.

Table 4. 95\% confidence intervals for peak torque at each of the measured angular velocities and for different positions in the field per leg.

\begin{tabular}{|c|c|c|c|c|c|c|}
\hline \multirow[b]{2}{*}{ Extension } & \multicolumn{2}{|c|}{ Peak torque $60(\mathrm{Nm})$} & \multicolumn{2}{|c|}{ Peak torque $180(\mathrm{Nm})$} & \multicolumn{2}{|c|}{ Peak torque $240(\mathrm{Nm})$} \\
\hline & Right & Left & Right & Left & Right & Left \\
\hline goalkeepers & $228.83-262.11$ & $232.43-260.07$ & $186.27-203.86$ & $182.32-203.15$ & $154.88-170.06$ & $151.92-169.28$ \\
\hline Defenders & $219.19-235.23$ & $210.41-227.43$ & $172.74-185.11$ & $169.40-179.22$ & $144.37-154.62$ & $138.47-149.53$ \\
\hline Midfielders & $224.64-239.63$ & $214.86-230.87$ & $167.48-178.93$ & 165.93-176.61 & $140.24-150.05$ & $141.31-150.56$ \\
\hline Strikers & $233.12-255.08$ & $218.60-241.26$ & $170.35-188.95$ & $170.99-184.80$ & $138.76-210.51$ & $143.31-156.80$ \\
\hline \multicolumn{7}{|l|}{ Flexion } \\
\hline Goalkeepers & $136.33-150.98$ & $119.13-139.12$ & $112.22-126.45$ & $97.76-114.71$ & $99.69-114.58$ & $87.89-102.84$ \\
\hline Defenders & $133.01-148.27$ & $123.02-141.60$ & $109.18-117.28$ & $102.68-110.16$ & $96.88-103.91$ & $89.07-97.60$ \\
\hline Midfielders & $135.60-143.89$ & $120.71-130.60$ & $108.03-120.93$ & $101.28-114.16$ & $95.85-102.53$ & $89.50-95.84$ \\
\hline Strikers & $134.82-148.36$ & $124.10-136.85$ & $112.42-123.65$ & $106.66-117.10$ & $104.43-113.78$ & $94.07-105.89$ \\
\hline
\end{tabular}


Table 5. 95\% confidence intervals for average work at each of the measured angular velocities and for different field positions per leg.

\begin{tabular}{c|c|c|c|c|c|c}
\hline & \multicolumn{2}{|c|}{ Average work $\mathbf{6 0}(\mathbf{J})$} & \multicolumn{2}{c}{ Average work 180 (J) } & \multicolumn{2}{c}{ Average work 240 (J) } \\
\hline Extension & Right & Left & Right & Left & Right & $113.37-126.07$ \\
\hline goalkeepers & $227.19-257.22$ & $200.97-247.55$ & $177.45-199.04$ & $175.75-198.86$ & $11.60-125.57$ \\
\hline Defenders & $207.26-223.18$ & $207.39-224.25$ & $167.12-179.74$ & $152.39-224.70$ & $110.13-119.49$ & $106.67-117.02$ \\
\hline Midfielders & $195.43-293.68$ & $211.73-228.61$ & $160.92-173.84$ & $164.52-176.51$ & $104.06-114.18$ & $109.26-117.52$ \\
\hline Strikers & $208.45-233.53$ & $206.25-230.17$ & $162.51-181.09$ & $166.00-181.00$ & $108.72-121.45$ & $111.12-122.66$ \\
\hline Flexion & & & & & & \\
\hline Goalkeepers & $145.67-167.10$ & $133.04-155-30$ & $112.39-127.20$ & $97.47-116.12$ & $70.55-83.32$ & $59.76-72.92$ \\
\hline Defenders & $141.59-154.83$ & $135.16-151.93$ & $110.81-120.04$ & $100.32-110.62$ & $71.39-78.67$ & $66.06-73.05$ \\
\hline Midfielders & $145.77-156.95$ & $135.16-146.83$ & $105.29-147.88$ & $100.45-112.80$ & $69.58-75.66$ & $62.18-68.89$ \\
\hline Strikers & $139.41-156.73$ & $134.40-149.52$ & $110.66-124.71$ & $106.14-117.38$ & $75.20-85.27$ & $69.30-77.91$ \\
\hline
\end{tabular}

Abbreviations: J, joule.

Several studies ${ }^{17,20,22}$ have reported similar values to those herein, whereas others found higher ${ }^{24-27}$ and lower values. ${ }^{21,23}$ Compared to the present study, Parpa ${ }^{26,28}$ with a large sample with similar anthropometric characteristics to ours obtained lower values for right and left leg extensions and similar values for flexor muscles. Eniseler ${ }^{23,25}$ also revealed results that corresponded to those in the present study, although the sample therein was smaller. Further, Cotte 20,22 found similar results in a sample of Premier League soccer players. However, lower values were revealed in some studies ${ }^{21-24}$ whereas higher values were exhibited in Fonseca's study ${ }^{24,26}$ where, on average, the participants were older than those in this study. In studies such as that of Ramírez ${ }_{1}^{12}$ in which the sample including anthropomorphic characteristics was similar to that employed herein, a clear parallel between the results for PTs in the extensions of both legs was revealed for the goalkeepers. However, the values of Ramírez ${ }^{12}$ were higher for the other positions. The training and anthropometric characteristics of goalkeepers may have contributed to the similarity of the results. However, although the players were tested at half speed in both studies, the players were tested at $180 \%$ s and $120 \% \mathrm{~s}$ in the present study and in that of Ramírez, 12 respectively.

Our study is among the few that address possible reference values in relation to average work and that compare work between soccer players who occupy different positions on the field. ${ }^{3,4}$

We are in complete agreement with Manou ${ }^{29}$ that work values could be the best indicators of endurence and we should take this fact in consideration. The measurement of average work, neglected on many occasions, seems necessary to evaluate the soccer player's resistance and fatigue. In our opinion, if the force over repititions is to be estimated more accurately, average work should be estimated rather than the maximum force at a given moment of the range of motion.
This study sought to establish benchmarks for each of the field positions; because significant differences between positions in the field for PT and average work at some tested angular velocities were found, one may refer to reference values not only in global terms for both variables, but also per position in the field. The present study proposes that an analysis of PT and average work to assess global muscle function. We consider that an optimal analysis of muscular capacity must also passes through adequate average work values.

This study eludicated the reference values for these players in relation to their position on the field. Health professionals might use these benchmarks to optimize soccer players' performances. Despite the progress made because of these reference values, the possible limits that the extrapolation of values between devices may have should be taken into consideration. 27,30 Nevertheless, the range of the proposed values may mitigate the inter-dynamometric variability.

\section{CONCLUSION}

The goalkeepers and strikers were the ones that showed the greatest differences in their fovor in relation to the rest of positions on the field. The isokinetic profile of professional soccer players has been described. It was noted that the profile varied in relation to the position in the field for PT and average work. In summary, the results of the present study can be a tool that health professionals working with professional soccer players in their care can use to assess and monitor a particular player.

All authors declare no potential conflict of interest related to this article

AUTHORS' CONTRIBUTIONS: GCS: conception, carrying out the work, interpretation or analysis of the data, preparation of the manuscript, revision of important intellectual content; FGSJ: conception, carrying out the work, preparation of the manuscript, revision of important intellectual content; LFR: conception, revision of important intellectual content, supervision and final approval; IBF: carrying out the of work; APG: carrying out the work, preparation of the manuscript; JMCR: interpretation or analysis of the data.

\section{REFERENCES}

1. FIFA. Professional football report 2019. https://img.fifa.com/image/upload/jlr5corccbsef4n4brde. pdf. Updated 2019. Accessed July $6^{\text {th }}, 2020$.

2. Baptista I, Johansen D, Seabra A, Pettersen SA. Position specific player load during match-play in a professional football club. PLoS One. 2018;13(5):e0198115. doi: 10.1371/journal.pone.0198115.

3. Śliwowski R, Grygorowicz M, Hojszyk R, Jadczak $Ł$. The isokinetic strength profile of elite soccer players according to playing position. PloS one. 2017;12(7):e0182177.

4. Goulart LF, Dias RMR, Altimari LR. Isokinetic force of under-twenties soccer players: Comparison of players in different field positions. Brazilian Journal of Kinanthropometry and Human Performance 2007;9(2):165-169.

5. Ayala F, de Baranda PS, de Ste Croix M, Santonja F. Validez y fiabilidad de los ratios de fuerza isocinética para la estimación de desequilibrios musculares. Apunts. Medicina de l'Esport. 2012;47(176):131-142.

6. Subasi F, Kayserilioglu A, Yergin Ç. Isokinetic strength and body composition of elite male soccer players during pre-season. Fizyoterapi Rehabilitasyon. 2004;15(2):61.

7. Bašćevan $S$, Knjaz D, Bašćevan A. Differences in various isokinetic indicators in elite soccer players. Hrvatski športskomedicinski vjesnik. 2007;22(2):86-90.
8. Henny J, Petitclerc C, Fuentes-Arderiu X, et al. Need for revisiting the concept of reference values. Clinical chemistry and laboratory medicine. 2000;38(7):589-595.

9. Altamirano KM, Coburn JW, Brown LE, Judelson DA. Effects of warm-up on peak torque, rate of torque development, and electromyographic and mechanomyographic signals. J Strength Cond Res. 2012;26(5):1296-1301. doi: 10.1519/JSC.0b013e31822e7a85.

10. Lehnert M, Xaverová Z, Croix MDS. Changes in muscle strength in U19 soccer players during an annua training cycle. Journal of Human Kinetics. 2014;42(1):175.

11. Perrin DH. Reliability of isokinetic measures. Athletic training. 1986;21(3):319-321.

12. Ramírez T, Manuel H. Torque máximo absoluto e índice convencional isocinético de rodilla en futbolistas profesionales del 2007 al 2012. 2014.

13. Cometti G, Maffiuletti N, Pousson M, Chatard J, Maffulli N. Isokinetic strength and anaerobic power of elite, subelite and amateur french soccer players. Int J Sports Med. 2001;22(01):45-51.

14. Amato $M$, Lemoine $F$, Gonzales J, Schmidt C, Afriat $P$, Bernard P. Influence de l'âge et de l'activité sportive sur le profil isocinétique des muscles quadriceps et ischio-jambiers de jeunes sportifs gymnastes et footballeurs. Annales de Réadaptation et de Médecine Physique. 2001;44(9):581-590. 
15. Rochcongar P, Morvan R, Jan J, Dassonville J, Beillot J. Isokinetic investigation of knee extensors and knee flexors in young french soccer players. Int J Sports Med. 1988;9(06):448-450.

16. Herdy CV, Galvao P, Silva GC, et al. Knee flexion and extension strength in young brazilian soccer players: The effect of age and position. Human Movement. 2018;19(3):23-29.

17. Tsiokanos A, Paschalis V, Valasotiris K. Knee extension strength profile of elite greek soccer players. Isokinetics Exerc Sci. 2016;24(1):79-82

18. Tourny-Chollet C, Leroy D, Léger H, Beuret-Blanquart F. Isokinetic knee muscle strength of soccer players according to their position. Isokinetics Exerc Sci. 2000;8(4):187-193.

19. White A, Hills SP, Cooke CB, et al. Match-play and performance test responses of soccer goalkeepers: A review of current literature. Sports Medicine. 2018;48(11):2497-2516.

20. Altavilla G, Mazzeo F, D'Elia F, Raiola G. Physical commitment and specific work for each role in an elite soccer team. Journal of Physical Education and Sport. 2018;18(2):570-574.

21. de Lira CAB, Mascarin NC, Vargas VZ, Vancini RL, Andrade MS. Isokinetic knee muscle strength profile in brazilian male soccer, futsal, and beach soccer players: A cross-sectional study. Int J Sports Phys Ther. 2017;12(7):1103-1110. doi: 10.26603/ijspt20171103.

22. Cotte T, Chatard J. Isokinetic strength and sprint times in english premier league football players. Biology of Sport. 2011;28(2):89.
23. Urzua R, Von Oetinger A, Cancino J. Potencia aeróbica máxima, fuerza explosiva del miembro inferiory peak de torque isocinético en futbolistas chilenos profesionales y universitarios. Revista Kronos. 2009;8(15).

24. Fousekis $K$, Tsepis E, Vagenas G. Multivariate isokinetic strength asymmetries of the knee and ankle in professional soccer players. J Sports Med Phys Fitness. 2010;50(4):465-474

25. Eniseler N, Şahan C, Vurgun H, Mavi H. Isokinetic strength responses to season-long training and competition in turkish elite soccer players. Journal of Human Kinetics. 2012;31(1):159.

26. Fonseca STd, Ocarino JM, da Silva PL, Bricio RS, Costa CA, Wanner LL. Characterization of professional soccer players' muscle performance. Revista Brasileira de Medicina do Esporte. 2007;13(3):143-147.

27. Magalhaes J, Oliveir A, Ascensao A, Soares J. Concentric quadriceps and hamstrings isokinetic strength in volleyball and soccer players. J Sports Med Phys Fitness. 2004;44:119-125.

28. Parpa K, Michaelides M. Peak isokinetic torques of football players participating in different levels in cyprus and lower limb asymmetries. Journal of Sports Science. 2017;5:250-255.

29. Manou V, Arseniou P, Gerodimos V, Kellis S. Test-retest reliability of an isokinetic muscle endurance test. Isokinetics Exerc Sci. 2002;10(4):177-181.

30. Thompson MC, Shingleton LG, Kegerreis ST. Comparison of values generated during testing of the knee using the cybex II plus ${ }^{\bullet}$ and biodex model B-2000 ${ }^{\bullet}$ isokinetic dynamometers. Journal of Orthopaedic \& Sports Physical Therapy. 1989;11(3):108-115. 